\title{
KEITH YANDELL AND THE PROBLEM OF EVIL
}

\author{
GEORGE I. MAVRODES
}

Department of Philosophy, The University of Michigan, Ann Arbor, MI 48109

In a recent paper, Keith Yandell introduces an argument which seems to make short work of the problem of evil. ${ }^{1}$ Unfortunately, this line of argument is radical. ly unsatisfactory, and the problem which the existence of evil poses for theism - whatever that problem is - cannot be disposed of in that ready way.

Yandell begins by calling attention to the following proposition:

(N) Necessarily, if God allows any evil, then He has morally sufficient reason for doing so.

And he goes on to say that if $(\mathrm{N})$ is true then any particular evil has the following property:

(P) If God exists, then He has morally sufficient reason for allowing this evil.

Yandell then asserts the crucial thesis of his argument. He says that "it seems clear that any evil that has $P$ is not an evil whose existence provides evidence against God's existence. An evil that has $\mathrm{P}$ is useless for the critic's purposes ... If $(\mathrm{N})$ is true, then every evil, and all evil together, is critically cancelled."

Now, it is true that if $(\mathrm{N})$ is true then $(\mathrm{P})$ is true of every actual evil (but it need not be true of every possible, or prospective, evil). This is so because, if God exists, then every actual evil is an evil which is allowed by God (whom Yandell assumes to be "omnicompetent"). But, according to (N), God allows no evil without a morally sufficient reason. Hence, if $(\mathrm{N})$ is true then (P) is true of every actual evil. And no doubt Yandell intended (P) to be construed as applying to actual evils, and not to merely possible evils. So far, so good.

But how does that show that if $(\mathrm{N})$ is true then every actual evil is "critically cancelled"?

Yandell provides no argument whatsoever for this claim. He says merely that "it seems clear." In fact, however, it is not at all clear. But we may hazard a conjecture about how it might come to "seem" clear. What is true is that an evil which 
is such that God has a morally sufficient reason for allowing it - which is, we might say, morally allowable by God - provides no genuine evidence against the existence of God. And it might be supposed that $(\mathrm{P})$ is the property of being morally allowable by God. If we were to construe (P) in this way, then we would get Yandell's conclusion and we would put an end to the problem of evil. In fact, however, (P) is not the property of being morally allowable by God. It is, rather, the conditional property of being morally allowable by God if God exists. And that is quite a different property.

Before going into this point somewhat further, we might note that Yandell's basic line of argument here need not be made to depend on $(\mathrm{N})$, or upon any other theological thesis. This might be of some importance for Yandell himself, because later in his paper he argues that $(N)$ is false. ${ }^{3}$ In fact, the status of $(N)$ is inconsequential for the present line of argument, for $(\mathrm{N})$ can be replaced by the following less controversial principle:

$\left(\mathrm{N}^{*}\right)$ Any two things which co-exist are logically compatible with one another.

If $\left(\mathrm{N}^{*}\right)$ is true, then any actual evil has the following property:

$\left(\mathrm{P}^{*}\right)$ If God exists, then His existence is logically compatible with the existence of this evil.

And if it seems clear that any evil which has (P) is critically cancelled, then it will also seem clear in the same way that any evil which has ( $\left.\mathrm{P}^{*}\right)$ is critically cancelled. For if an evil has the property of being compatible with the existence of God, then it does not provide genuine evidence against the existence of God. And ( $\left.\mathrm{P}^{*}\right)$ might be thought to be the property of being compatible with the existence of God.

Not only does Yandell's line of argument here need no theological assumptions, it need not be restricted to any theological context. It can be used to argue that no fact whatsoever provides any evidence against anything at all. Everything is thus critically cancelled.

Think, for example, of a murder. It is widely suspected that the friendly neighborhood hit man, affectionately known as "Shark," is the murderer. But it is soon established as an undeniable fact that:

(M) Less than half an hour after the murder, Shark was attending a symposium on medical ethics 300 miles away.

Some people believe that (M) provides evidence, practically conclusive evidence, against the hypothesis that Shark is the murderer. A Yandellian, however, would easily argue that this is not the case. He would observe that since Shark's attendance at the symposium is an actual event it must have the following property: 
(P') If Shark committed the murder, then his committing the murder is compatible with this event.

And it will seem clear to him that no event which has (P') can provide evidence against Shark's having committed the murder. But, of course, this strategy can be mounted against any proposed evidential fact whatsoever. Everything is thus critically cancelled.

And we may, not surprisingly, come to suspect that there is something fishy about this line of argument.

What is wrong here is that ( $\left.\mathrm{P}^{\prime}\right)$ is (or represents) a merely conditional property. It is quite possible, therefore, that Shark's attendance at the symposium is such that $\left(\mathrm{P}^{\prime}\right)$ is true of it, and also such that the following proposition is true of it:

(K) This event is completely incompatible with Shark's having committed the murder.

And the epistemic bearing of Shark's attendance at the symposium on the possibility of his having committed the murder is a function of $(\mathrm{K})$ rather than of $\left(\mathrm{P}^{\prime}\right)$. Or, we might say, $(\mathrm{K})$ dominates $\left(\mathrm{P}^{\prime}\right)$ with respect to evidential significance. If both (K) and (P') are true of that event, then Shark did not commit the murder.

The trouble with both of the more theological principles, $(\mathrm{P})$ and $\left(\mathrm{P}^{*}\right)$, for Yandell's purposes, is that they too are (or represent) merely conditional properties. They are hypotheticals whose antecedent is "God exists." If this antecedent is true, then indeed every actual evil is morally allowable by God and is logically compatible with God. But if the antecedent is false, then some actual evils may have the conditional properties $(\mathrm{P})$ and $\left(\mathrm{P}^{*}\right)$ even if they also have the categorical properties of not being morally allowable by God and not being logically compatible with God. We cannot, therefore, determine whether any actual evil has the property of being compatible with the existence of God merely by noting that it has property $(\mathrm{P})$ or $\left(\mathrm{P}^{*}\right)$. Indeed, if $\left(\mathrm{N}^{*}\right)$ is true, then every actual state of affairs, whether evil or not, has $\left(\mathrm{P}^{*}\right)$. But with respect to the evidential force of an actual evil, these properties are dominated by the presence or absence of the property of compatibility with the existence of God. That is where the theist must make his argument.

We can think of the dialectical situation in this way. Suppose that the professed atheist, developing his version of the problem of evil, calls attention to some actual evil, $E_{1}$, and asserts that $E_{1}$ is so bad, so destructive, so pointless, etc., etc., that

(1) $E_{1}$ cannot be morally allowable by God, and it is logically incompatible with the existence of (an omnicompetent) God.

He then concludes that

(2) Therefore, there is no (omnicompetent) God. 
Now, a person who accepts Yandell's claim about the critical cancellation of evils might insist on asserting that

(3) If God exists, then He has a morally sufficient reason for allowing $E_{1}$, and/or if God exists, then His existence is logically compatible with the existence of $E_{1}$.

The atheist, however, has no objection at all to (3). He accepts it cheerfully (as well as accepting the principles from which it is derived). He says that he is quite willing to add it to the premises of his own argument. He takes it to be a necessary truth, and he says that making it explicit will simply make the structure of his argument clearer. For (1) and (3) formally entail (2) by modus tollens. What could be clearer than that?

How can the theist get anything valuable for his own purposes out of these hy* potheticals? He might assert

(4) God exists.

(4) and (3) together entail the denial of (1), and that would seem to be fatal to the atheist's argument. This strategy, however, would not be open to Yandell. For he begins his paper by saying that it would be inappropriate, in a discussion of the problem of evil, to assume that God exists. Without (4), however,(3) seems to be of no use to the theist. (3), in fact, is the common property of the theist and the atheist. In conjunction with (1) it entails the denial of (4). And in conjunction with (4) it entails the denial of (1).

In a context, therefore, in which the existence of God can be assumed and appealed to, principles such as $(\mathrm{P})$ and $\left(\mathrm{P}^{*}\right)$ are useful to the theist. They enable him to infer the status of the actual evils in the world vis à vis God. But in a context in which the theist cannot already appeal to the existence of God, these principles are useless. It seems unlikely, therefore, that they will divert the force of any serious objection based on the existence of evil in the world.

\section{NOTES}

1. Keith Yandell, "The Problem of Evil and the Content of Morality." International Journal for Philosophy of Religion 17/3 (1985), 139-165.

2. Ibid., pp. 140, 141 .

3. Ibid., p. 163. 